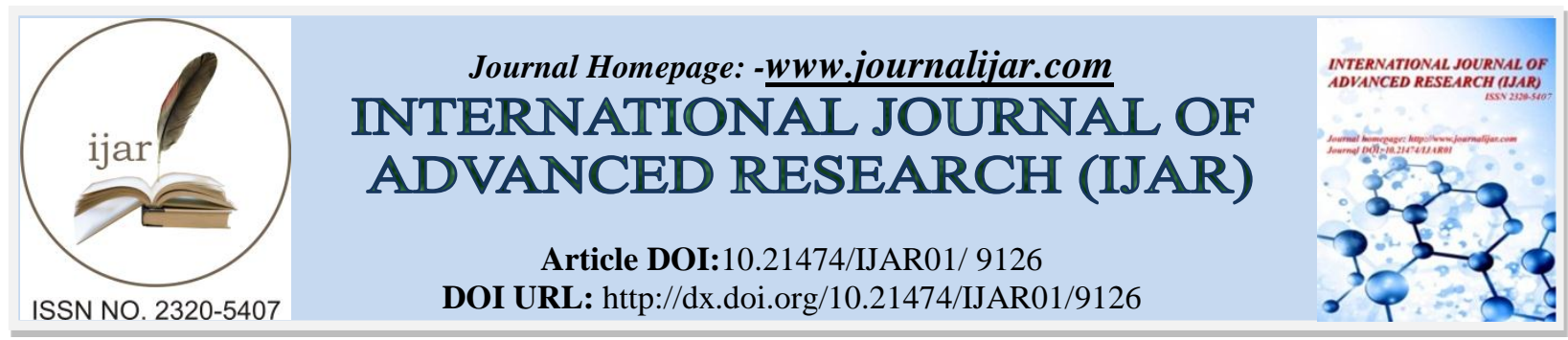

RESEARCH ARTICLE

\title{
TO STUDY THE COMPLICATIONS OF LAPAROSCOPIC SURGERY SPECIFIC TO ABDOMINAL PROCEDURES.
}

Dr.Akshay Bahadur and Dr.Vivek loomba.

\section{Manuscript Info}

Manuscript History

Received: 24 March 2019

Final Accepted: 26 April 2019

Published: May 2019
Abstract

Copy Right, IJAR, 2019,. All rights reserved.

\section{Introduction:-}

Scar less surgery is the Holy Grail of surgery and the main aim of minimal access surgery was the reduction of scars and thereby pain and suffering of patients. The choice of therapeutic possibilities has increased considerably since the development of minimally invasive procedures. The advantages of this approach include decreased scarring, decreased incisional pain, shorter hospitalization, and faster functional recovery. Laparoscopy has been shown to be a great surgical improvement compared to laparotomy [1]. Blood loss reduction, smaller scars, less pain, and shorter hospital stays are few advantages of laparoscopy over laparotomy. However Laparoscopy has been associated with complications including physiologic changes during peritoneal insufflation, access-related complications, subcutaneous emphysema (SE), pneumothorax, gas embolism, port site hernias, as well as injuries to diaphragm, blood vessels, Omentum, viscera, and bladder etc. This study was conducted in order to observe the complications and associated risk factors of laparoscopic surgery specific to abdominal procedures.

Aim:-

1. Incidence of the complications in laparoscopic surgery specific to abdominal procedures

2. To evaluate factors influencing the rate of complications

\section{Material And Methods:-}

1. Study population- Indoor patients in surgery department of SGGRIM\&HS/

2. Study subject- Patients undergoing laparoscopic procedures in department of surgery SGGRIM\&HS.

3. Study design - prospective follow up study.

\section{Inclusion criteria-}

1. Age between $18-75$ years

2. Patients undergoing laparoscopic surgery for appendicular disease, gall bladder disease, hernia and diagnostic laparoscopy

3. Patients undergoing laparoscopic surgery for above mentioned reason would be selected

\section{Exclusion criteria-}

1. Age $<18$ years and $>75$ years

2. Patients undergoing laparoscopic surgery for any other cause except appendicular disease, gall bladder disease, hernia and diagnostic laparoscopy

3. Laparoscopic surgeries done for emergency cases 


\section{Sampling:--}

Approximately 400 laparoscopic procedures take place in one year and we took a sample size of 100 patients. Every third patient was taken as my study subject via random selection till sample size of 100 was achieved

\section{Study tool:--}

Predesignated and Pretested questionnaire

\section{Study duration:-}

1 year period

\section{Compilation and tabulation of data done}

Statistical analysis -

Collective data analysed on appropriate software. Statistical test for significance done by applying chisquare test.

\section{Results and observations:-}

Table 1.1:-Total Number Of Patients

\begin{tabular}{|l|l|c|c|}
\hline SN & \multicolumn{1}{|c|}{ PROCEDURE } & NUMBER & PERCENTAGE \\
\hline 1 & LAPAROSCOPIC CHOLECYSTECTOMY & 91 & $91 \%$ \\
\hline 2 & LAPAROSCOPIC APPENDECTOMY & 6 & $6 \%$ \\
\hline 3 & TAPP & 1 & $1 \%$ \\
\hline 4 & DIAGNOSTIC LAPAROSCOPY & 2 & $2 \%$ \\
\hline
\end{tabular}

Table 1.2:-Total Number Of Complications

\begin{tabular}{|l|c|c|}
\hline \multicolumn{1}{|c|}{ CRIETARIA } & NUMBER & \multicolumn{2}{c|}{ PERCENTAGE } \\
\hline PATIENTS WITH COMPLICATIONS & 6 & $6 \%$ \\
\hline PATIENTS WITHOUT COMPLICATIONS & 94 & $94 \%$ \\
\hline
\end{tabular}

\begin{tabular}{|l|c|c|}
\hline \multicolumn{1}{|c|}{ CRIETARIA } & NUMBER & PERCENTAGE \\
\hline POST OP HEMORRHAGE & 1 & $16.66 \%$ \\
\hline BILE LEAKAGE & 1 & $16.66 \%$ \\
\hline PORT SITE INFECTION & 1 & $16.66 \%$ \\
\hline CAUTERY INJURY & 2 & $33.33 \%$ \\
\hline VERESS NEEDLE INJURY & 1 & $16.66 \%$ \\
\hline
\end{tabular}

Note:-Table 1.2 shows that incidence of complications was $6 \%$, while complications specific to laparoscopic procedures was $3 \%$.

Note:-Table 1.2 shows that incidence of complications was $6 \%$ while complications specific to laparoscopic procedures was $3 \%$

Table 1.3:-Age Distribution

\begin{tabular}{|l|l|l|l|l|l|}
\hline & NUMBER & $\begin{array}{l}\text { WITH } \\
\text { COMPLICATIONS }\end{array}$ & PERCENTAGE & $\begin{array}{l}\text { WITHOUT } \\
\text { COMPLICATIONS }\end{array}$ & PERCENTAGE \\
\hline $\begin{array}{l}\text { MORE THAN } \\
\text { 60 YRS }\end{array}$ & 14 & 5 & $35.7 \%$ & 9 & $64.3 \%$ \\
\hline UPTO 60 YRS & 86 & 1 & $1.2 \%$ & 85 & $98.8 \%$ \\
\hline
\end{tabular}

Table 1.4:-Distribution On Basis Of Sex

\begin{tabular}{|l|l|l|l|l|l|}
\hline & NUMBER & WITH COMPLICATION & $\%$ & $\begin{array}{l}\text { WITHOUT } \\
\text { COMPLICATION }\end{array}$ & $\%$ \\
\hline MALE & 24 & 4 & $16.7 \%$ & 20 & $83.3 \%$ \\
\hline FEMALE & 76 & 2 & $2.6 \%$ & 74 & $97.4 \%$ \\
\hline
\end{tabular}

Table 1.17:-distribution showing association of complications to body weight of patient:

\begin{tabular}{|l|l|l|l|l|l|}
\hline BODY WEIGHT & TOTAL & WITH & $\%$ & WITHOUT & $\%$ \\
\hline
\end{tabular}




\begin{tabular}{|l|l|l|l|l|l|}
\hline & & COMPLICATIONS & & COMPLICATIONS & \\
\hline UPTO 60 KG & 71 & 1 & $1.4 \%$ & 70 & $98.6 \%$ \\
\hline$>60 \mathrm{KG}$ & 29 & 5 & $17.2 \%$ & 24 & $82.8 \%$ \\
\hline
\end{tabular}

Table 1.18:-distribution of complications according to presence of smoking habit:

\begin{tabular}{|l|l|l|l|l|l|}
\hline SMOKING & TOTAL & WITH COMPLICATIONS & $\%$ & $\begin{array}{l}\text { WITHOUT } \\
\text { COMPLICATIONS }\end{array}$ & $\%$ \\
\hline PRESENT & 12 & 1 & $8.3 \%$ & 11 & $91.7 \%$ \\
\hline ABSENT & 88 & 5 & $5.7 \%$ & 83 & $94.3 \%$ \\
\hline
\end{tabular}

Table 1.19:-Distribution Of Complications According To Presence Of Alcohol Consumption

\begin{tabular}{|l|l|l|l|l|l|}
\hline $\begin{array}{l}\text { ALCOHOL } \\
\text { CONSUMPTION }\end{array}$ & TOTAL & $\begin{array}{l}\text { WITH } \\
\text { COMPLICATION }\end{array}$ & $\%$ & $\begin{array}{l}\text { WITHOUT } \\
\text { COMPLICATION }\end{array}$ & $\%$ \\
\hline PRESENT & 8 & 1 & $12.5 \%$ & 7 & $87.5 \%$ \\
\hline ABSENT & 92 & 5 & $5.4 \%$ & 87 & $94.6 \%$ \\
\hline
\end{tabular}

Table 2.1:-Analysis To Determine Risk Factors For Elective Abdominal Laproscopic Procedures

\begin{tabular}{|c|c|c|c|c|c|c|c|c|c|}
\hline \multirow{4}{*}{\multicolumn{2}{|c|}{ Variables }} & \multirow{5}{*}{$\begin{array}{l}n \\
86\end{array}$} & \multirow{2}{*}{\multicolumn{4}{|c|}{ Complication }} & & \multirow[b]{4}{*}{$95 \%$ CI } & \\
\hline & & & & & & & \multirow{4}{*}{$\begin{array}{l}\text { Odds } \\
\text { Ratio } \\
1.00\end{array}$} & & \multirow{3}{*}{$\begin{array}{l}\text { p } \\
\text { Value }\end{array}$} \\
\hline & & & \multicolumn{2}{|c|}{ Present } & \multicolumn{2}{|c|}{ Absent } & & & \\
\hline & & & No. & $\%$ & No. & $\%$ & & & \\
\hline Age & $\leq 60$ years & & 1 & 1.2 & 85 & 98.8 & & & 0.001 \\
\hline & $>60$ years & 14 & 5 & 35.7 & 9 & 64.3 & 47.22 & $4.96-449.95$ & \\
\hline Sex & Female & 76 & 2 & 2.6 & 74 & 97.4 & 1.00 & & 0.012 \\
\hline & Male & 24 & 4 & 16.7 & 20 & 83.3 & 7.40 & $1.26-43.35$ & \\
\hline SMOKER & Present & 12 & 1 & 8.3 & 11 & 91.7 & 1.02 & $0.86-1.23$ & 0.54 \\
\hline & Absent & 88 & 5 & 5.7 & 83 & 94.3 & 1 & & \\
\hline & Present & 8 & 1 & 12.5 & 7 & 87.5 & 1.08 & $0.83-1.41$ & 0.40 \\
\hline ALCOHOLIC & Absent & 92 & 5 & 5.4 & 87 & 94.6 & 1 & & \\
\hline WEIGHT & $<60 \mathrm{~kg}$ & 71 & 1 & 1.4 & 70 & 98.6 & 1 & $1.01-1.41$ & 0.007 \\
\hline & $>60 \mathrm{~kg}$ & 29 & 5 & 17.2 & 24 & 82.8 & 1.19 & & \\
\hline
\end{tabular}

Note :-

1. Odds ratio is a measure of association between an exposure and an outcome. The odds ratio represents the odds that an outcome will occur given a particular exposure, compared to the odds of the outcome occurring in the absence of that exposure. [4]

2. The p value or calculated probability, is the probability of finding the observed, or more extreme, results when the null hypothesis of a study question is true. [5]

3. Confidence interval (CI) is a type of interval estimate of a population parameter. It is an observed interval, in principle different from sample to sample, that potentially includes the unobservable true parameter of interest. [6]

Table 2.1 shows that-

1. Odds of having complication in the patient aged more than 60 years is 47.22 as compared to patient aged $\leq 60$ years and this was found to be statistically significant.

2. Significantly higher odds (1.19) of having complication was seen in patients whose weight was more than 60 $\mathrm{kg}$.

3. Significantly higher odds (7.40) of having complication was seen among males as compared to females.

\section{Discussion:-}

In this study we found that overall complications related to laparoscopic procedures was $6 \%$ while complications specific to laparoscopic procedures was $3 \%$. Our results are comparable to a study done by Ohio Digestive Disease Institute, Grant Medical Centre, Columbus, Ohio in 1991 in which they performed 283 consecutive laparoscopic cholecystectomies with no deaths and a morbidity rate of 5.3\% (15 of 283 patients; six major complications, nine minor complications).[3] 
Our study shows that odds of having complication in the patient aged more than 60 years is 47.22 as compared to patient aged $\leq 60$ years and this was found to be statistically significant which was comparable to results of study done by Swiss Association of Laparoscopic and Thoracoscopic Surgery (SALTS) database where multivariable analysis showed that age $(\mathrm{OR}=1.12$ per 10 years; $\mathrm{p}<0.0001)$ was found to be associated with a higher incidence of postoperative local complications. [2]

In our study significantly higher odds (1.19) of having complication was seen in patients whose weight was more than $60 \mathrm{~kg}$ while multivariable analysis data from the Swiss Association of Laparoscopic and Thoracoscopic Surgery (SALTS) database showed that body weight $(>90 \mathrm{~kg}$ versus $<60 \mathrm{~kg}$; OR $=1.34 ; \mathrm{p}<0.0001$ ) was independently associated with an increased intraoperative local complication rate. The difference in weight is due difference in built of the two races. [2]

\section{Conclusion:-}

Laparoscopy has greatly improved surgical outcomes in many areas of elective abdominal surgery. In day care surgery, laparoscopy is becoming widely accepted and used with significant advantages in the majority of patients undergoing day care surgery in certain centres with specific experience and laparoscopic skills.

Laparoscopy has been shown to be a great surgical improvement compared to laparotomy. The advantages of this approach include decreased scarring, decreased incisional pain, shorter hospitalization, and faster functional recovery.

However Laparoscopy has been associated with complications including physiologic changes during peritoneal insufflations, access-related complications, subcutaneous emphysema (SE), pneumothorax, gas embolism, port site hernias, as well as injuries to diaphragm, blood vessels, Omentum, viscera, urinary bladder and cautery injuries etc. This study showed that incidence of complications in laparoscopic surgery specific to abdominal procedures was $6 \%$ while complications specific to laparoscopic procedures was $3 \%$.

General complications encountered in our study included post-operative haemorrhage, post-operative bile leakage and port site infections while complications specific to laparoscopic surgery included complications due to altered anatomy and technical difficulties like Veress needle induced injury and cautery injury .

Our study also showed that factors associated with complications which included:-

1. Patient aged more than 60 years

2. Patients whose weight was more than $60 \mathrm{~kg}$

3. Male gender

Therefore these factors should be kept in mind when one is planning to do a laparoscopic surgery specific to abdominal procedures so as to decrease the complication rate.

\section{Refrences:-}

1. Semim K. Atlas of Gynaecological Laparoscopy and Hysteroscopy. 2nd ed. Philadelphia: WB Saunders; 1977.7.

2. Urs F Giger, Jean-Marie Michel, Isabelle Opitz, Devdas Th Inderbitzin,Thomas Kocher, Lukas Krähenbühl. Risk Factors for Perioperative Complications in Patients Undergoing Laparoscopic Cholecystectomy. Swiss Association of Laparoscopic and Thoracoscopic Surgery (SALTS) Study Group1003doi:10.1016/j.jamcollsurg.2006.07.011003

3. Peters JH1, Gibbons GD, Innes JT, Nichols KE, Front ME, Roby SR, Ellison EC. Complications of laparoscopic cholecystectomy; Surgery. 1991 Oct; 110(4):769-77.

4. Magdalena Szumilas. Explaining Odds Ratios. J Can Acad Child Adolesc Psychiatry. 2010 Aug; 19(3): 227- 229 .

5. www.statsdirect.com/help/basics/p_values.html

6. en.m.wikipedia.org/wiki/Confidence_interval. 